\title{
EFFECT OF AIR FLOW RATE OF WINNOWING FAN ON PERFORMANCE OF RICE COMBINE HARVESTER MACHINE
}

El- Attar, M.A., * M.A. Khodeir, * A.A. Soliman, * and H.El-Khateeb*

ABSTRACT

Field experiments were carried out at the experimental field of Rice Mechanization center, Meet El-Deeba, kafre El-Sheikh Governorate, Egypt. Japanese combine harvesting machine, yanmar model CA- 385 (hold-in), cutting width $1400 \mathrm{~mm}$, crawler traveling unit, adjusted pick tines and star wheels, were tested at three air flow rates of $(0.25,0.32$ and $\left.0.40 \mathrm{~m}^{3} / \mathrm{s}\right)$ and three different forward speeds of $(0.94,1.62$ and 2.88 $\mathrm{km} / \mathrm{h}$ ). The combine test to harvest rice variety (Sakha 101).

The results revealed that all kinds of losses (header and threshing) was minimum of 0.69 and $0.90 \%$ at forward speed of $0.94 \mathrm{~km} / \mathrm{h}$. Also, the lowest value of cleaning and total losses was 0.30 and $1.89 \%$ at air flow rate $0.25 \mathrm{~m}^{3} / \mathrm{s}$ and forward speed of $0.94 \mathrm{~km} / \mathrm{h}$, respectively.

The highest value of combine performance efficiency was $98.0 \%$ at air flow rate of $0.25 \mathrm{~m}^{3} / \mathrm{s}$ and forward speed of $0.94 \mathrm{~km} / \mathrm{h}$.

By decreasing the air flow rate from 0.40 .0 .32 and $0.25 \mathrm{~m}^{3} / \mathrm{s}$ tends to increase the whole grain from (79.2, 80.7 and 84.3\%), empty grain form (0.44, 0.55 and 0.81\%), impurity from $(0.35,0.51$ and $1.0 \%)$ and grain with pedicel from (8.3, 13.8 and 16.4\%), respectively, at forward speed of $0.94 \mathrm{~km} / \mathrm{h}$.

Increasing the forward speed from $0.94,1.62$ and $2.88 \mathrm{~km} / \mathrm{h}$ tends to decrease the criterion cost from 99.7,98.2and 97.3 LE/fed.

\section{INTRODUCTION}

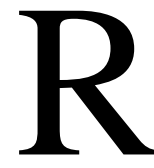
ice crop is one of the most major cereal crops in Egypt. More than 1.468 million feddans are cultivate yearly with rice as per year and the national average yield was 4.2 ton per feddan (Agricultural Research Center, 2006).

\footnotetext{
*Agric. Eng. Res. Inst., El-Dokki - Giza - Egypt.
} 
It is evident that, increasing any production for quantity and quality, does not depend only improvement of soil and plant conditions, but largely on using improved methods technology to fulfill the agriculture process in correct time and keep down production cost.

Grain losses due to these operations reach at least $25 \%$ of total yield in addition to poor quality of the grains. As a result for that, in addition to labour shortage during harvesting periods; the need for reliable alternative techniques for rice harvesting became a necessity. Combine harvesters represent a possible solution for these problems. Afify, et al. (2000) studies is to select the proper system of rice harvesting suits the planting methods. They showed the lowest total cost by using drilling plant and Deutz fahr combine for harvesting (188.21 LE/fed). The increasing total cost of drilling plant and harvesting by using yanmar combine (237.21 LE/Fed) was largest comparing with total losses between them. Badr, et al. (2007) studied the effect of some planting and harvesting methods on rice crop yield. They found that the maximum seed productivity (4187 $\mathrm{kg} / \mathrm{Fed}$ ) was obtained by using manual transplanting and big combine and the minimum yield (2946 kg/fed) was obtained by using seed drill and manual harvesting + Barmeel (Barrel) thresher. Also, the highest net profit (5556 LE/fed) was obtained with using manual transplanting and big combine and the lowest (3829 LE/fed) was obtained by using seed drill and manual harvesting and Barmeel thresher. El-khateeb (2005) recommended that using mutt-purpose combine harvester (Yanamar model CA760 with cutting width of about $2 \mathrm{~m}$ ) to harvest rice crop variety Sakha 102 was the most efficient and economic system $(89.7 \mathrm{LE} / \mathrm{fed})$ compared with manual harvesting followed by thresher (181.6 LE/fed). El-Nakib, et al. (2003a) used kubota combine (pro-481) as a mechanical harvester of rice (Sakha 102). Header, threshing, separating and shoe losses increased with increasing of the forward speed and the decrease of grain moisture content. The shoe losses increase from $(0.24$ to $1.05 \%)$ with the increase of air fan velocity from $(6.17$ to $7.67 \mathrm{~m} / \mathrm{s})$. The optimum operating harvesting rice crop was at combine forward speed of $4.5 \mathrm{~km} / \mathrm{h}$ and grain moisture content of $16.5 \%$. El-Raie et al. (2012) improved the performance of combine machines during the harvesting 
operation of cereal crops is important to minimize both grain losses and operational costs. They found that the better results were reached under operating conditions was found to be as threshing drum speed of $500 \mathrm{rpm}$, feed rate of $2000 \mathrm{~kg} / \mathrm{h}$, operating forward speed of $1.22 \mathrm{~km} / \mathrm{h}$, cylinder concave clearance of $(12.54 / 5.5 \mathrm{~mm})$ at grain moisture content of $21 \%$ was found to be as the developed rotor ( 7 teeth), whereas the total grain losses of $1.68 \%$, required energy of $30.186 \mathrm{kw} . \mathrm{h} / \mathrm{fed}$, operating costs of 223.50 LE/fed., threshing efficiency of $99.34 \%$, separation efficiency of $99.27 \%$ and cleaning efficiency of $99.71 \%$. Kamel (1999) using two different types of combine harvesting machines namely combine yanmar model CA-385 and multi-purpose combine yanmar model CA-760 to harvest three rice varieties. He proved that all kinds of losses (header, drum and shoe losses) increased with the increase of cutting height and harvesting speed for both tested combines with three rice varieties and the lowest value of losses were obtained at harvesting speed of $0.3 \mathrm{~m} / \mathrm{s}$ and cutting height of $7 \mathrm{~cm}$. Kepner et al. (1982) found that seed losses a combine can occur in connection with any of the four basic operations these losses are often identified as header, cylinder, walker and shoe losses. Gathering losses in direct combining include heads, pods or ears and free seed, lost during the cutting and conveying operations. Morad and fouda (2003) develop long axial flow rice thresher (Barmeel thresher) to be suitable for threshing rice crop with high efficiency and low power consumption. Increasing input capacity from 1.8 to 2.5 ton/h at constant drum speed of $24.64 \mathrm{~m} / \mathrm{s}$, increasing threshing power by 14.12 and $11.69 \%$ for threshers before and after development, respectively. Also, increasing drum speed from 21.51 to $36.70 \mathrm{~m} / \mathrm{s}$, at constant input capacity of 2.25 ton/h increased threshing power by 14.12 and $11.69 \%$ for threshers before and after development, respectively. It is clear that improving the performance of combine devices during the harvesting operation of rice crop is of great importance to minimum both grain losses and operational costs. So, the objective of this study is to investigate grain losses due to the different functional parts and to determine the possible optimum operating conditions for the harvesting operation of rice crop. 


\section{MATERIALS AND METHODS}

Field experiments were carried out at the experimental field of the Rice Mechanization Center, Kafr El-Sheikh Governorate, Egypt, The combine harvesting machine, namely, combine Yanmar model CA-385 were used to harvest of rice crop (Sakiha 101). Table (1) summarized the technical specifications.

Table 1: Technical specifications of combine harvester

\begin{tabular}{|l|l|}
\hline \multicolumn{1}{|c|}{ Specifications } & \multicolumn{1}{|c|}{ Combine harvester yanmar CA-385) } \\
\hline Overall length $(\mathrm{mm})$ & 4063 \\
\hline Overall width $(\mathrm{mm})$ & 1904 \\
\hline Overall height $(\mathrm{mm})$ & 2160 \\
\hline Cutting width $(\mathrm{mm})$ & 1400 \\
\hline Cutting height $(\mathrm{mm})$ & Hydraulically adjusted \\
\hline Engine type & Diesel, 3 cylinder, 4 strokes, water cooled \\
\hline Out-put Ps/rpm & $48 / 2800$ \\
\hline Threshing unit type & Shaking sieves and fans \\
\hline Threshing drum length $(\mathrm{mm})$ & 710 \\
\hline Threshing drum diameter $(\mathrm{mm})$ & 420 \\
\hline Traveling unit & Crawler \\
\hline
\end{tabular}

\section{Laboratory test:}

1- The soil and grain moisture content measured by using electric oven at $105 \mathrm{C}^{\mathrm{o}}$ for $24 \mathrm{hr}$.

2- $\quad$ Measuring shattering habit force $(\mathrm{N})$ for rice.

3- Determination of grain quality by three samples each of $500 \mathrm{~g}$ were taken from each treatments. Percentage of these samples were calculated for whole, empty, impurity (rubbish and chuff) and grain with pedicels.

\section{Procedure:}

The experiment procedures were carried by combine harvester at three forward speeds $(0.94,1.62$ and $2.88 \mathrm{~km} / \mathrm{h})$ and three air flow rates $(0.25$, 0.32 and $0.40 \mathrm{~m}^{3} / \mathrm{s}$ ) were studies to harvest of rice crop (Sakha 101).

\section{Crop characteristic:}

Crop condition is an important factor for the performance of harvesting machine and has a great effect for grain losses and final grain condition and yield. 
Table2:Mean values of crop characteristics of rice variety Sakha 101.

\begin{tabular}{|l|l|}
\hline Characteristic & Unit \\
\hline Plant height, $\mathrm{cm}$ & 86.7 \\
\hline No. of panicles/m ${ }^{2}$ & 509.7 \\
\hline Weight of grain/10 panicle, gm & 27.5 \\
\hline No. of hills/m ${ }^{2}$ & 24.0 \\
\hline No. o panicles/hill & 19.3 \\
\hline Weight of 1000 grain, gm & 27.9 \\
\hline Grain moisture content, \% & 24.0 \\
\hline Row space, cm & 30 \\
\hline Hill space, cm & 17.5 \\
\hline Cutting width, cm & 14.0 \\
\hline Cutting height, cm & 8.0 \\
\hline Shattering habit, N & 1.9 \\
\hline Standing angle, deg. & 80.5 \\
\hline Yield, ton & 4.2 \\
\hline
\end{tabular}

\section{Harvesting losses:}

a) pre-harvest losses determine:

$$
\text { Pre-harvest losses } \%=\frac{\text { pre }- \text { harvest losses } / \text { Fed }}{\text { Total Yield } / \text { Fed }} \times 100
$$

b) Header losses determine:

$$
\text { Header losses } \%=\frac{\text { Header losses } / \text { Fed }}{\text { Total Yield } / \text { Fed }} \times 100
$$

c) Threshing losses determine: determine:

$$
\text { Threshing losses } \%=\frac{\text { Threshing losses } / \text { Fed }}{\text { Total Yield } / \text { Fed }} \times 100
$$

d) Cleaning (shoe) losses determine:

$$
\text { Cleaning (shoe) losses } \%=\frac{\text { Shoe }(\text { cleaning losses } / \text { Fed }}{\text { Total Yield } / \text { Fed }} \times 100
$$

Combine performance efficiency:

$$
\text { Performance efficiency } \%=\frac{\text { out put } / \text { Fed }}{(\text { out put }+ \text { Total losses }) / \text { Fed }} \times 100
$$

* The machine out put is the amount of grain collected in the bin of harvester.

* Total losses of combine (header, threshing and shoe losses). 
Machine performance:

Effective field capacity (E.F.C.):

E.F.C. $=\frac{1}{\text { Effective total time in hours tequired per feddan }}=\mathrm{Fed} / \mathrm{h}$.

Efficiency (E):

$\mathbf{E}=\frac{\text { E.F.C. }}{\text { T.F.C. }} \times 100$

Soil hardness for paddy field:

A Japanese soil electrometer model SR-2, DIK 5500 was used to evaluate soil penetration resistance for soil before and after harvesting operation Table (3).

Table 3: Average soil penetration resistance in $\mathrm{kg} / \mathrm{cm}^{2}$ before and after harvesting for paddy field:

\begin{tabular}{|c|c|c|}
\hline $\begin{array}{c}\text { Soil } \\
\text { depth, } \\
\text { cm }\end{array}$ & $\begin{array}{c}\text { Soil penetration resistance } \\
\text { before harvesting, } \\
\mathrm{kg} / \mathrm{cm}^{2}\end{array}$ & $\begin{array}{c}\text { Soil penetration resistance } \\
\text { after harvesting, } \\
\mathrm{kg} / \mathrm{cm}^{2}\end{array}$ \\
\hline 0 & 4.50 & 6.0 \\
\hline 5 & 8.00 & 10.0 \\
\hline 10 & 10.00 & 12.0 \\
\hline 15 & 12.00 & 14.0 \\
\hline 20 & 16.01 & 17.5 \\
\hline 25 & 18.03 & 19.0 \\
\hline 30 & 15.00 & 16.0 \\
\hline 35 & 12.50 & 13.0 \\
\hline 40 & 10.00 & 11.5 \\
\hline
\end{tabular}

Note : The reading for soil hardness in representing the means of five reading average soil moisture content of $23.0 \%$

\section{Criterion cost:}

The criterion cost of the harvesting operation was estimated by using the following equation (El-Awady, et al., 1982).

Criterion cost $/ \mathrm{Fed}=$ Operating cost $(\mathrm{LE} / \mathrm{fed})+$ grain loss $(\mathrm{LE} / \mathrm{Fed})$

Operating cost $(\mathrm{LE} / \mathrm{fed})=\frac{\text { Machin } \cos t(\mathrm{LE} / \mathrm{h})}{\text { Effective Field capacity }(\mathrm{Fed} / \mathrm{h})} \mathrm{L} \cdot \mathrm{E} / \mathrm{Fed}$

\section{Air flow rate of winnowing fan:}

The hot wire anemometer is easily used to measure air velocity of winnowing fan-Air velocity, $\mathbf{S}(\mathbf{m} / \mathbf{s})$ should be measured at many points in 
the window frame to gain the mean value. The air flow rate of winnowing fan, $\mathbf{V}\left(\mathrm{m}^{3} / \mathbf{s}\right)$ is calculated by the mean air velocity $\mathbf{S}(\mathbf{m} / \mathbf{s})$ multiplied by the area $\mathbf{A}\left(\mathbf{m}^{2}\right)$ of a window as the following equation:

$$
\mathbf{V}=\mathbf{S} \times \mathbf{A}, \mathbf{m}^{3} / \mathbf{s} \text {. }
$$

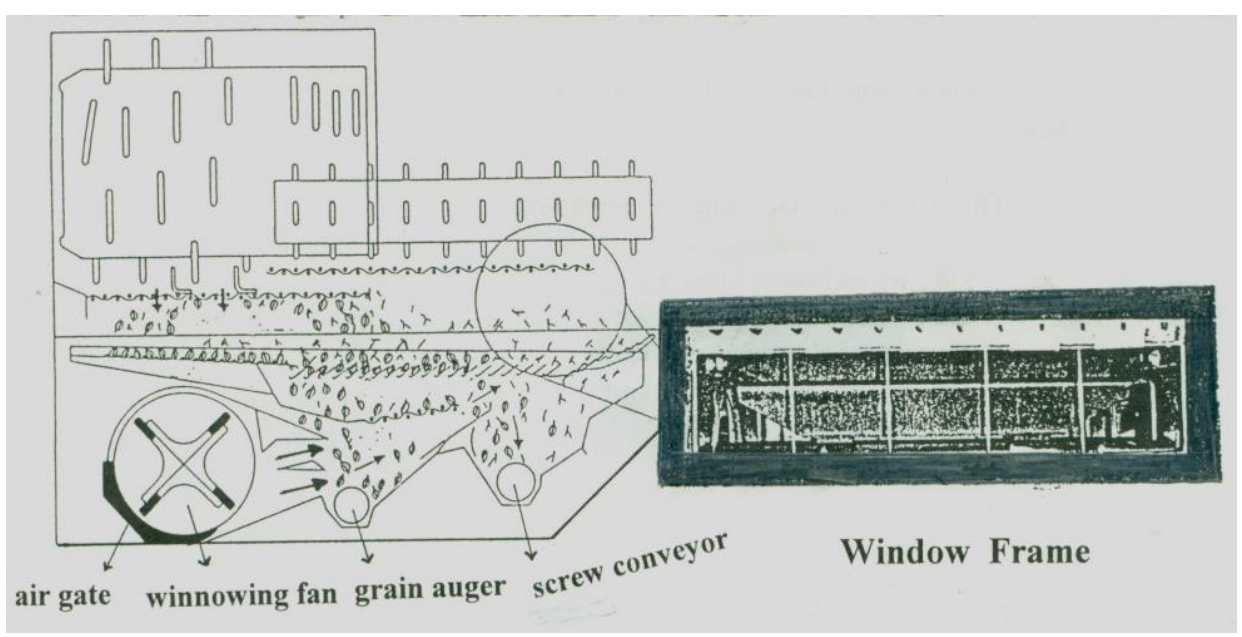

\section{RESULTS AND DISCUSSION}

1- Effect of forward speed $(\mathrm{km} / \mathrm{h})$ and air flow rate $\left(\mathrm{m}^{3} / \mathrm{s}\right)$ on the following indicators:

\section{Header and threshing losses, $\%$ :}

Table (4) indicates the effect of forward speed on header and threshing losses, \%. It is obvious that increasing the forward speed from $0.94,1.62$ and $2.88 \mathrm{~km} / \mathrm{h}$ tends to increase the header losses from $0.69,0.78$ and $0.99 \%$. Also, increased the threshing losses from $0.9,1.0$ and $1.1 \%$.

\section{Field performance characteristic of combine harvester:}

\section{1- Effective field capacity and efficiency:}

Table (4) indicates the effective field capacity increased by increasing by increasing the forward speed. The obtained values were $0.67,0.90$ and $1.20 \mathrm{fed} / \mathrm{h}$ at forward speed of 0.94 .1 .62 and $2.88 \mathrm{~km} / \mathrm{h}$.

Also, increasing the forward speed tends to decrease field efficiency. The forward speed of about $0.94,1.62$ and $2.88 \mathrm{~km} / \mathrm{h}$ gave field efficiency of about $86.3,84.1$ and $80.0 \%$. 
Table 4: Effect of forward speed and air flow rate on quality of performance.

\begin{tabular}{|c|c|c|c|c|c|c|}
\hline $\begin{array}{c}\text { Forward } \\
\text { speed, } \\
\mathbf{( k m} / \mathbf{h})\end{array}$ & $\begin{array}{c}\text { Air flow } \\
\text { rate, } \\
\left(\mathbf{m}^{\mathbf{3} / \mathbf{s}}\right)\end{array}$ & $\begin{array}{c}\text { Header } \\
\text { losses, } \\
(\mathbf{\%})\end{array}$ & $\begin{array}{c}\text { Drum } \\
\text { losses, } \\
(\mathbf{\%})\end{array}$ & $\begin{array}{c}\text { Field } \\
\text { capacity } \\
\mathbf{\text { Fed/h }}\end{array}$ & $\begin{array}{c}\text { Field } \\
\text { efficiency, } \\
\mathbf{\%}\end{array}$ & $\begin{array}{c}\text { Fuel } \\
\text { Consumption } \\
\mathbf{L} / \mathbf{h}\end{array}$ \\
\hline 0.94 & 0.40 & 0.69 & 0.9 & 0.67 & 86.3 & 4.1 \\
\hline & 0.32 & & & & & \\
\hline & 0.25 & & & & & \\
\hline 1.62 & 0.40 & 0.78 & 1.0 & 0.90 & 84.1 & 4.4 \\
\hline & 0.32 & & & & & \\
\hline & 0.25 & & & & & \\
\hline 2.88 & 0.40 & 0.99 & 1.1 & 1.20 & 80.0 & 4.9 \\
\hline & 0.32 & & & & & \\
\hline & 0.25 & & & & & \\
\hline
\end{tabular}

\section{2- Fuel consumption, $(\mathrm{L} / \mathrm{h})$ :}

Table (4) demonstrates the effect of forward speed on the rate of fuel consumption. The forward speeds of $0.94,1.62$ and $2.88 \mathrm{~km} / \mathrm{h}$ gave the following values of fuel consumption rate of $4.1,4.4$ and $4.9 \mathrm{~L} / \mathrm{h}$.

Fig.1 demonstrates the effect of forward speed and air flow rates on cleaning losses, \%. Increasing forward speed tends to increase shoe loses due to the excessive load of materials on the sieves. The forward speed of $0.94,1.62$ and $2.88 \mathrm{~km} / \mathrm{h}$ gave cleaning losses $0.70,0.80$ and $0.95 \%$ at air flow rate of $0.40 \mathrm{~m}^{3} / \mathrm{s}$. It is also apparent that the cleaning losses increased from $0.40,0.50$ and $0.80 \%$ by increasing air flow rate form 0.25 0.32 and $0.40 \mathrm{~m}^{3} / \mathrm{s}$ at forward speed of $1.62 \mathrm{~km} / \mathrm{h}$.

Fig.2 illustrated the effect of forward speed and air flow rates on total losses, \%. The obtained values of total losses were 2.29, 2.58 and 3.04\% at forward speed of $0.94,1.62$ and $2.88 \mathrm{~km} / \mathrm{h}$ at air flow rate of $0.40 \mathrm{~m}^{3} / \mathrm{s}$. Fig. 3 shows the effect of forward speed and air flow rate on the combine performance efficiency. It is clear that the performance decreased by increasing the forward speed at all air flow rates. The forward speed of about $0.94,1.62$ and $2.88 \mathrm{~km} / \mathrm{h}$ gave values of combine performance efficiency of about $97.0,96.0$ and $95.0 \%$ at air flow rate of about 0.32 $\mathrm{m}^{3} / \mathrm{s}$. It can be noticed that increasing the air flow rates from $0.25,0.32$ and $0.40 \mathrm{~m}^{3} / \mathrm{s}$ tends decreasing the performance efficiency from 98.0 , 97.0 and $96.0 \%$ at forward speed of $0.94 \mathrm{~km} / \mathrm{h}$.

Figs.4,5,6, and 7 shows the effect of forward speed and air flow rates on quality of work. Increasing the air flow rates from $0.25,0.32$ and 0.40 
$\mathrm{m}^{3} / \mathrm{s}$ tends to decrease the whole grains percentage from $(84.3,80.7$ and $79.2 \%)$, empty grains from $(0.81,0.55$ and $0.44 \%)$, impurity from (1.0, 0.51 and $0.35 \%)$ and grain with pedicel from (16.4, 13.8 and 8.3\%), respectively, at forward speed of $0.94 \mathrm{~km} / \mathrm{h}$. The other forward speeds had the same trend.

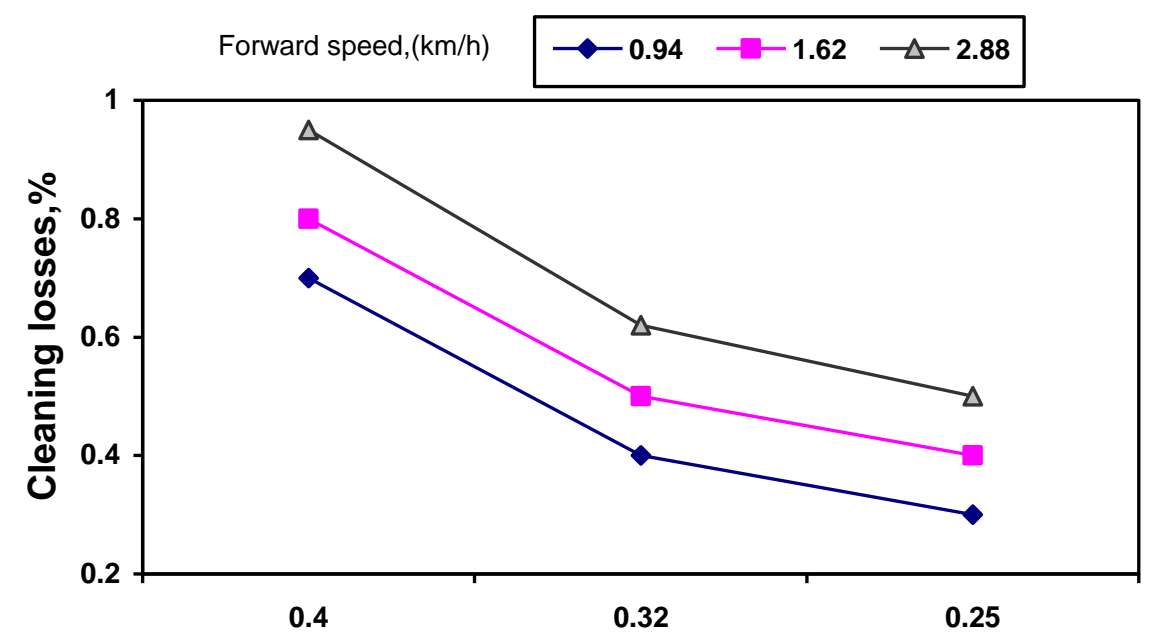

Fig.1 :- Effect of forward speed, and air flow rate on cleaning losses, \%.

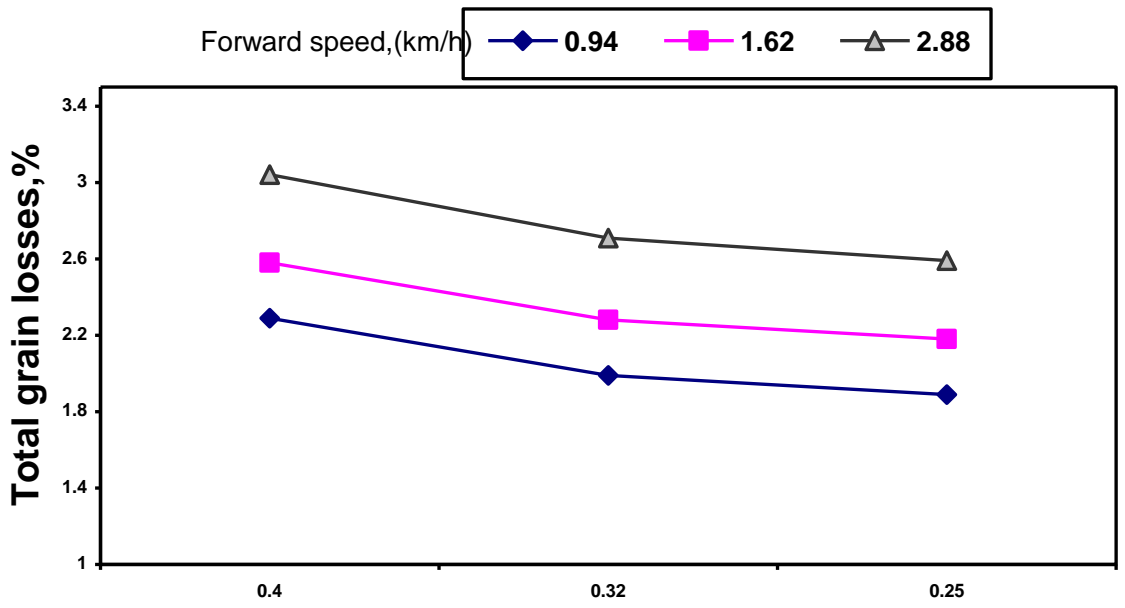

Fig.2 :- Effect of forward speed, and air flow rate on total grain losses, $\%$ 


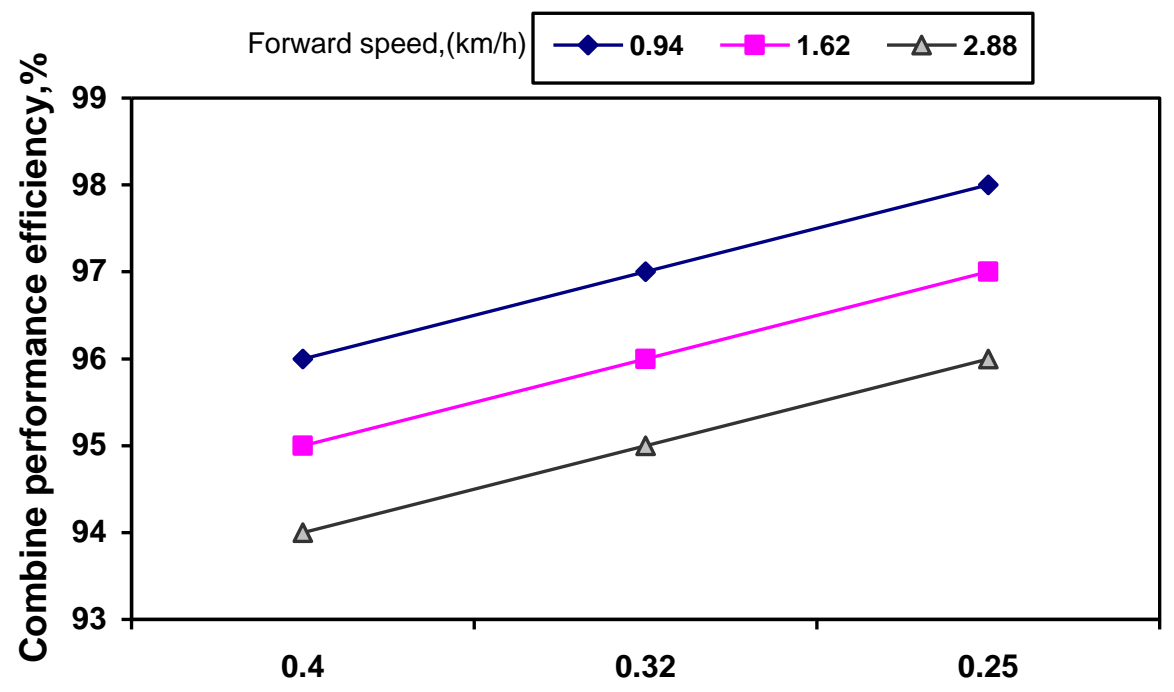

Fig.3 :- Effect of forward speed, and air flow rate on combine performance efficiency, $\%$.

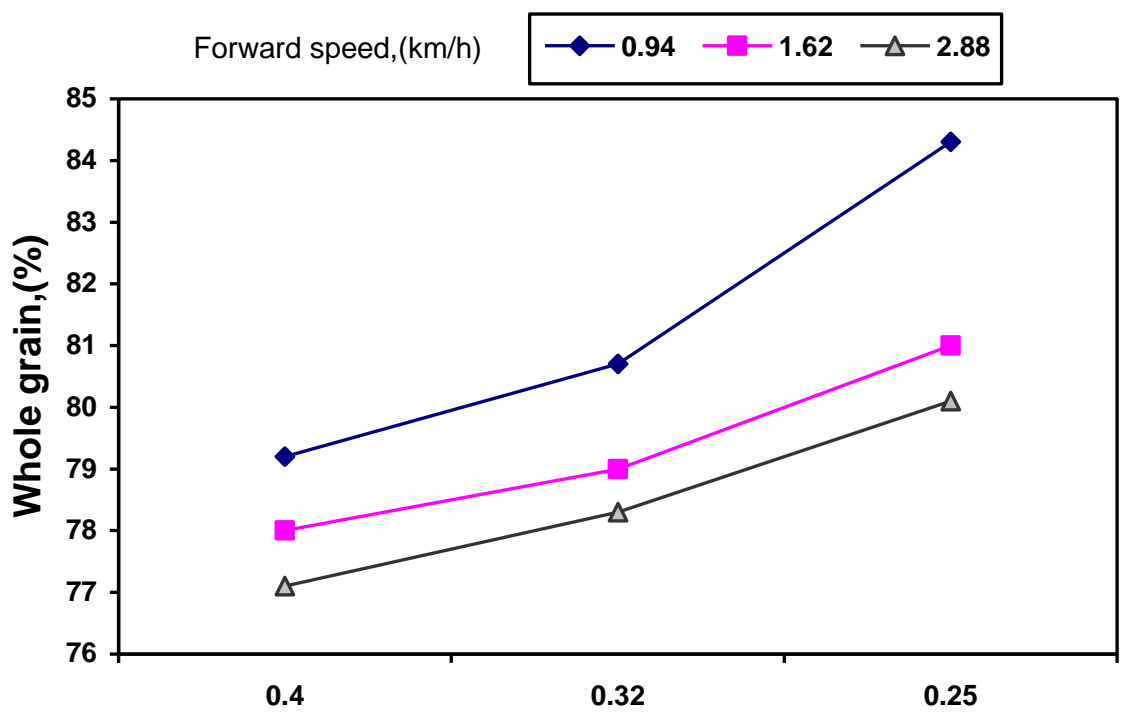

Fig.4 :- Effect of forward speed, and air flow rate on whole grain, $\%$. 


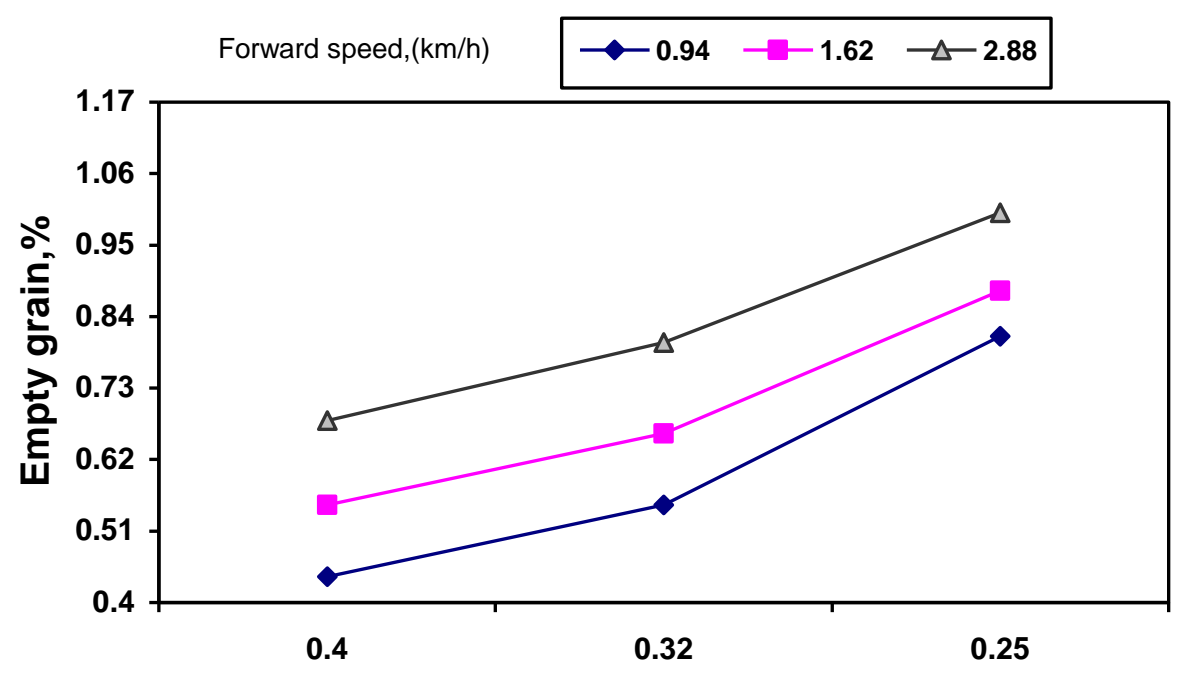

Fig.5 :- Effect of forward speed, and air flow rate on empty grain,\%.

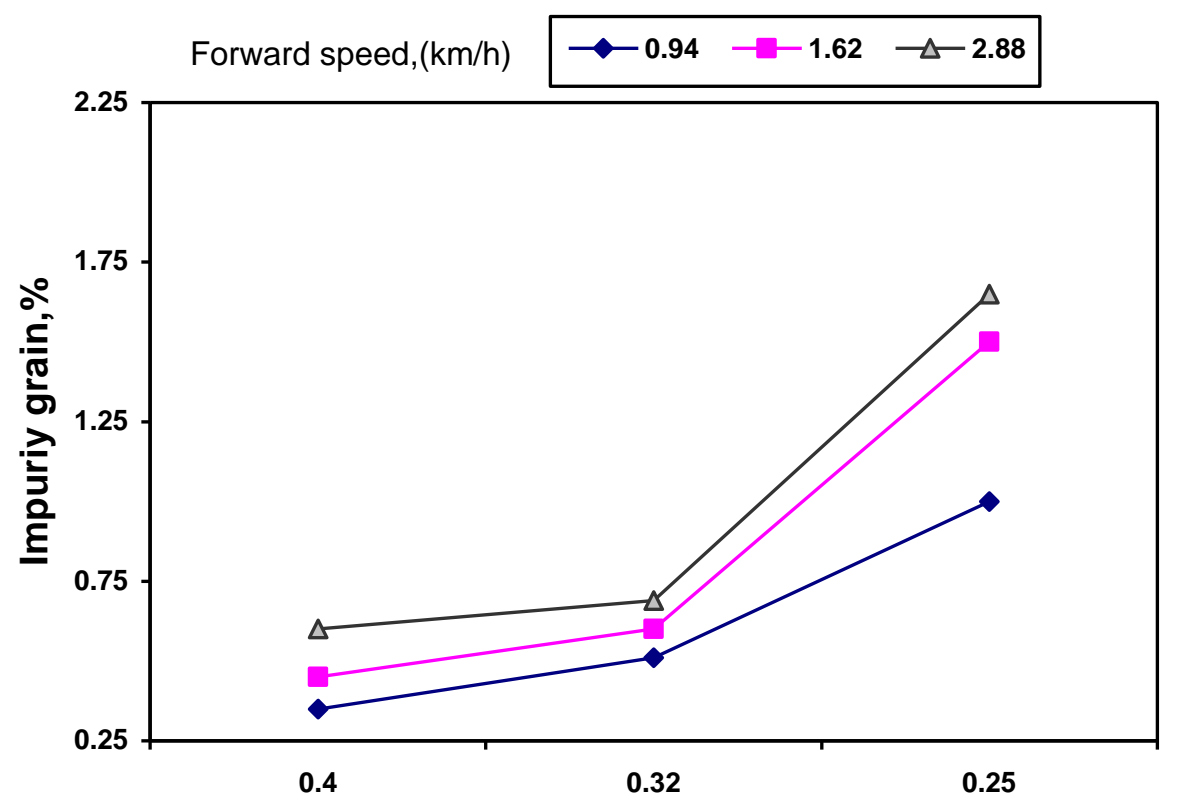

Fig.6 :- Effect of forward speed, and air flow rate on impurity grain,\%. 


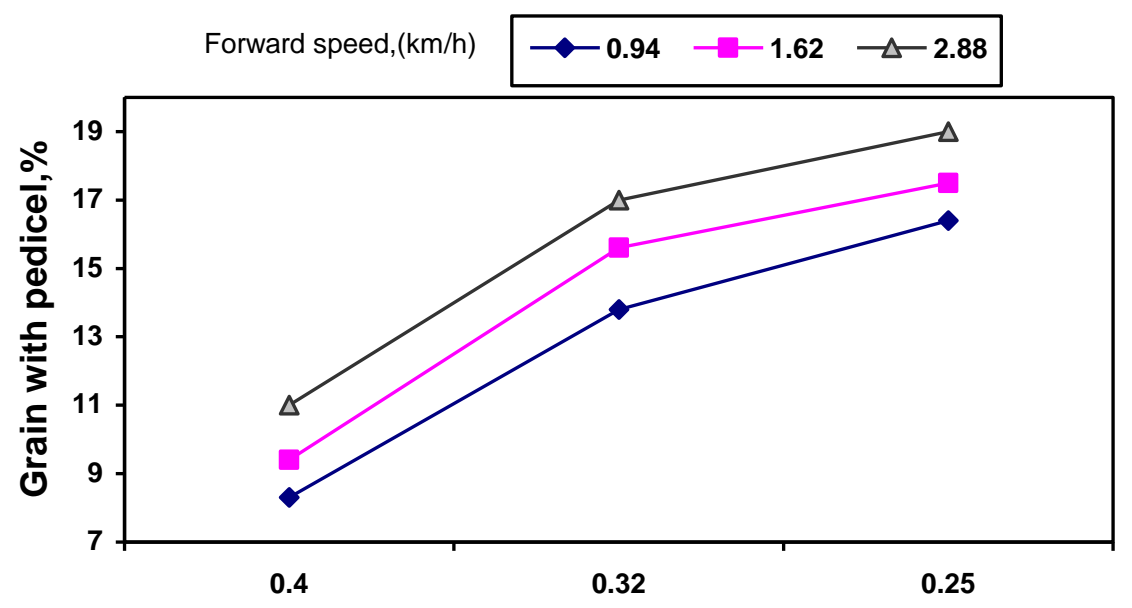

Fig.7 :Effect of forward speed, and air flow rate on grain with pedicel, $\%$.

\section{Machine criterion cost:}

Fig.8 indicates the effect of the combine forward speed and air flow rates on the criterion cost of the harvesting operation. The forward speed of about $0.94,1.62$ and $2.88 \mathrm{~km} / \mathrm{h}$ gave the following values of $98.3,97.4$ and $96.8 \mathrm{LE} /$ fed at air flow rate of about $0.32 \mathrm{~m}^{3} / \mathrm{s}$.

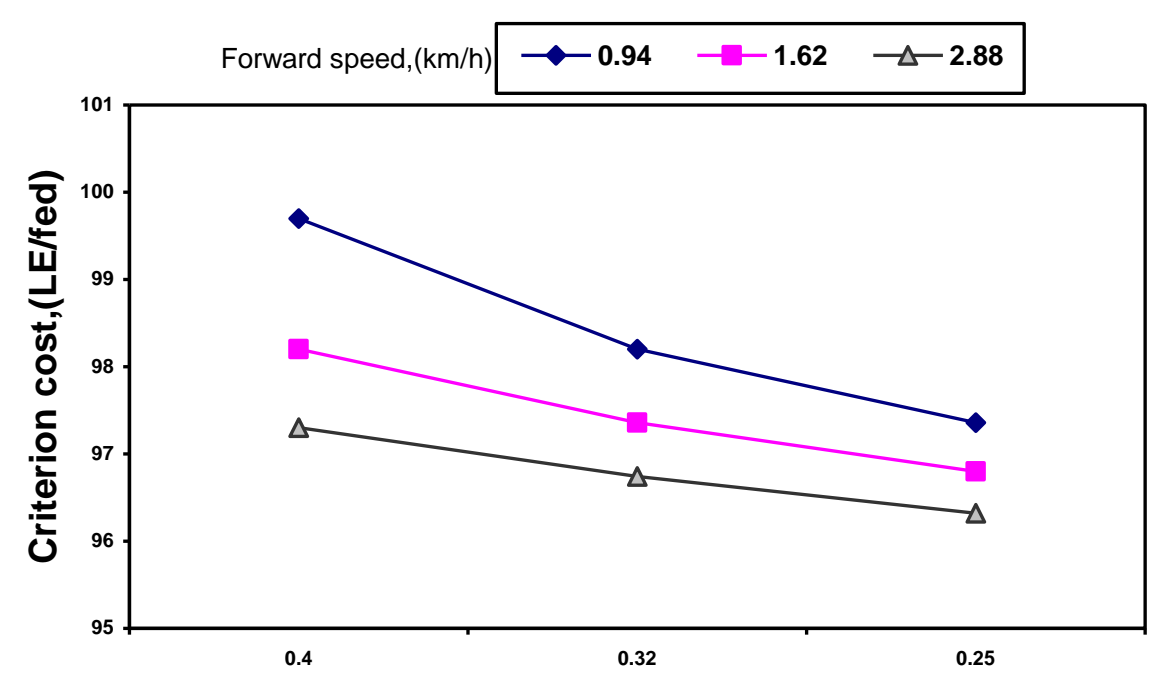

Fig.8 :- Effect of forward speed, and air flow rate on criterion cost,(LE/fed) 


\section{CONCLUSION}

The experimental results revealed the following points:

1- The minimum values of header and threshing losses was 0.69 and $0.90 \%$ at forward speed of $0.94 \mathrm{~km} / \mathrm{h}$.

2- The lowest value of cleaning and total losses was 0.30 and $1.89 \%$ at air flow rate of $0.25 \mathrm{~m}^{3} / \mathrm{s}$ and forward speed of $0.94 \mathrm{~km} / \mathrm{h}$.

3- The highest value of combine performance efficiency was $98.0 \%$ at air flow rate of $0.25 \mathrm{~m}^{3} / \mathrm{s}$ and forward speed of $0.94 \mathrm{~km} / \mathrm{h}$.

4- Increasing the forward speed from $0.94,1.62$ and $2.88 \mathrm{~km} / \mathrm{h}$ tends to decrease the criterion cost from 99.7,98.2 and 97.3 LE/Fed.

5- By decreasing the air flow rate from $0.40,0.32$ and $0.25 \mathrm{~m}^{3} / \mathrm{s}$ tends to increase the whole grain from (79.2. 80.7 and 84.3\%), empty grain from $(0.44,0.55$ and $0.81 \%)$, impurity from $(0.35,0.51$ and $1.0 \%)$ and grain with pedicel from $(83,13.8$ and $16.4 \%)$ respectively, at forward speed of $0.94 \mathrm{~km} / \mathrm{h}$.

\section{REFERENCES}

Agricultural research center Issue, 2006, Technical Recommendation for Rice crop, Ministry of Agic., Rice Prog. Issue No. 1014, Egypt: 5-7.

Afify, M.K., A. Nada and W.M.Mechail (2000). Selection the proper system of planting and harvesting rice crop. Misr J.Ag. Eng., 17 (2): 388-400.

Badr, S., H.Gindy; B. Hemido and A.M.El-lithy (2007). Planting and Harvesting Method Effects on Rice Productivity. Misr J.Ag. Eng., 24 (2): 318-326.

El-Awady, M.N.; E.Y. Ghoneim and I.Hashish (1982). A critical comparison between wheat combine harvesters under Egyptian conditions. Res. Bul. No. 1920 Col. Ag. An -Shams univ., 13p.

El-Khateeb, H.A. (2005). A study on performance of axial flow combine harvester in rice crop harvesting. Misr J. Ag. Eng.,22(4):381-401.

El-Nakib, A.A.; Z.Y.Abdel-Lateef; A.A. El-Messery and A. Khateeb (2003a). Mechanical harvesting losses in rice crop using combine harvester. Misr J.Ag. Eng., 20 (4): 889-907.

El-Raie, A.S.; A. Taieb, and M. Atallah (2012). Development of threshing system in combine harvester for improving of its 
peformance efficiency in rice threshing. Misr J. Ag. Eng., 29 (1): 143-178.

Kamel, O.M. (1994). Rice harvesting losses utilization two different harvesting techniques of japanes. Misr J. Ag. Eng., 16 (4): 237-251.

Kepner, R.A., R. Bainer and E.L. Barger (1982). Principles of farm machinery. $4^{\text {th }}$. Ed. John W.and Sons, Ins: 381-428.

Morad, M.M. and T.fouda (2003). Development of long-axial flow rice thresher shaft for minimum threshing power. Misr J. Ag. Eng., 20 (2): 391-404.

\section{الملخص العربي}

تأثير معدل سريان الهواء لمروحة التذرية على أداء آلة الحصاد الجامعة للأرز د/محمود العطار *، د د/ محمد خضير** ، د د/عبد الجواد علي سليمان* و أ د/حمادة على الخطيب* أصبحت الحاجة ملحة في إيجاد نظام بديل للحصاد اليدوي التقليدي وحل مشكلة عدم ثوافر العمالة اللازمة وقت الذروة وتقليل الفاقد في المحصول. ويهذف هذا البحث إلى دراسة فوافد حصاد الأزر الجزئية والكلية عند بعض عو امل التشغيل المختلفة وقد تم دراسة بعض تأثثر عو امل التشغيل على أداء آلة حصاد جامعة ياباني موديل

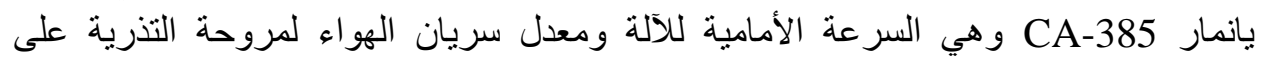

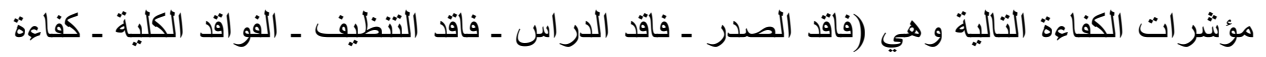
الأداء للكومباين ـ السعة الحقلية الفعلية ـ استهلاك الوقية الوقود ـ معيار التكاليف).

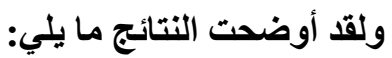

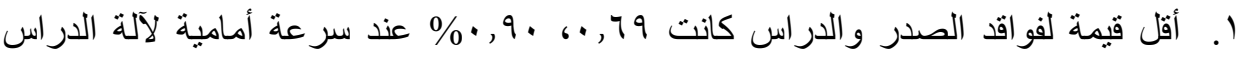

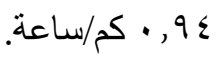

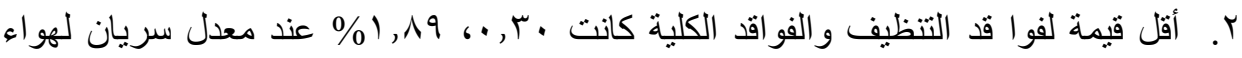

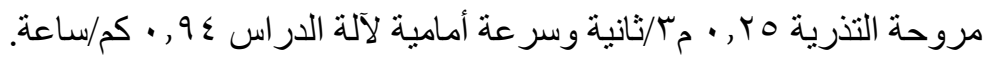

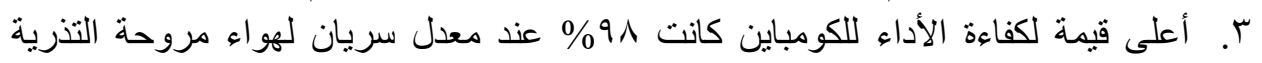

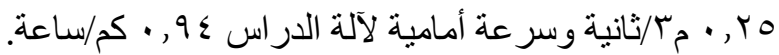

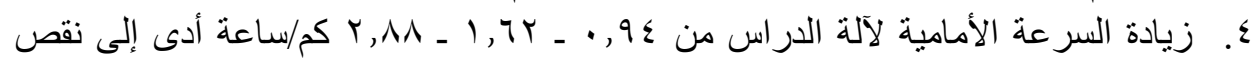

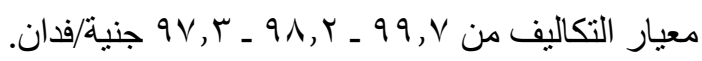

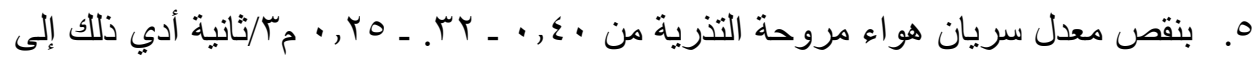

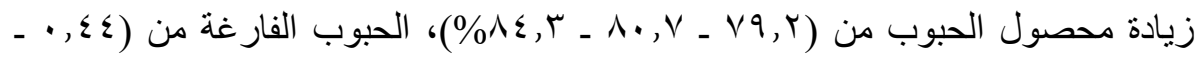

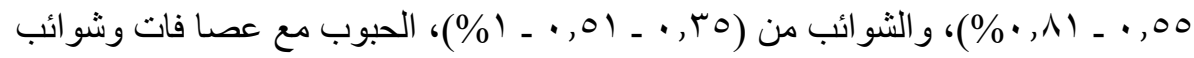

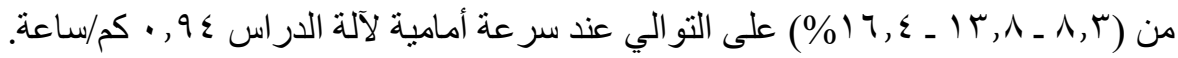

